\title{
THE STUDY OF ANTIMICROBIAL ACTIVITY OF AgNPS MADE BY USING GREEN SYNTHESIS AGAINST SPECIFIC MICROORGANISMS
}

\author{
1 Jiri SOCHOR, ${ }^{1,2,3}$ Karel SEHNAL, ${ }^{4}$ Maria RUIZ-RICO, ${ }^{4}$ Edgar Perez-ESTEVE, \\ ${ }^{1}$ Lenka SOCHOROVA, ${ }^{1}$ Mojmir BARON, ${ }^{4}$ Jose M. BARAT, ${ }^{1,2,3}$ Rene KIZEK \\ ${ }^{1}$ Mendel University in Brno, Faculty of Horticulture, Department of Viticulture and Enology, Lednice, \\ Czech Republic, EU, tomaskova.I.9@gmail.com \\ ${ }^{2}$ Department of Research and Development, Prevention Medicals s.r.o., Studénka-Butovice, \\ Czech Republic, EU, karelsehnal15@gmail.com \\ ${ }^{3}$ Department of Human Pharmacology and Toxicology, University of Veterinary and Pharmaceutical \\ Sciences Brno, Czech Republic, EU, kizek@sci.muni.cz \\ ${ }^{4}$ Grupo de Investigación e Innovación Alimentaria, Departamento de Tecnología de Alimentos, Universitat \\ Politècnica de València, Camino de Vera s/n, 46022 Valencia, Spain Maria Ruiz Rico \\ maruiri@etsia.upv.es
}

https://doi.org/10.37904/nanocon.2019.8766

\begin{abstract}
This work is focused on studying the antimicrobial effect of silver nanoparticles made by green synthesis. For the green synthesis, extracts from Salvia officinalis were used. Four different temperatures $\left(20,40,60,80^{\circ} \mathrm{C}\right)$ were used to prepare the extracts from the plant material. The antimicrobial capability of the AgNPs was assessed using different yeasts (Saccharomyces cerevisiae, Zygosaccharomyces bailii), gram-positive (Lactobacillus plantarum, Listeria innocua, Staphylococcus Aureus) and gram-negative (Escherichia coli, Acetobacter aceti) bacterial strains. The range of AgNPs concentrations $0-2,500 \mu \mathrm{g} / \mathrm{mL}$ were tested. The antimicrobial effect was studied using two methods: 1) the viable cell count method and 2) the inhibition zone method. The method of direct counting showed a small inhibitory effect (inhibition at concentrations 1,250 and $2,500 \mu \mathrm{g} / \mathrm{ml}$ ) only for E. coli, Z. bailii and S. cerevisiae. The inhibition zone results displayed better antibacterial activity of the silver nanoparticles (inhibition at all concentrations - 50, 100, 150 and $200 \mu \mathrm{g} / \mathrm{mL}$ ) prepared by using the extract obtained at $20^{\circ} \mathrm{C}$ against $E$. coli and S. aureus.
\end{abstract}

Keywords: Green synthesis, silver nanoparticles, antimicrobial activity

\section{INTRODUCTION}

The process of green synthesis in nanoparticle production has become a more and more popular alternative to chemical synthesis in recent years. It is a simple, inexpensive and environmentally friendly method for producing nanoparticles. Biosynthesised nanoparticles show high biocompatibility and antimicrobial, antioxidant, antidiabetic, anticancer and other effects, and thus have the potential to be widely used in many fields $[1,2]$.

Silver nanoparticles produced by green synthesis are abundantly studied for their antimicrobial properties $[3,4]$. This is primarily based on the biological matrix of the sample. Parameters in the production of nanoparticles such as temperature, $\mathrm{pH}$, extraction time and individual production processes play an important role [5,6].

Salvia officinalis, used in our work as a reducing agent, contains a significant amount of antioxidant components. It contains essential oils, tannins, phenolic substances and flavonoids $[7,8]$. The production of essential oils, which are contained in the leaves, is significant [9].

This work aimed to determine the inhibitory effect of AgNPs on selected bacteria and yeasts. In the second part, the aim was to test the effect of AgNPs prepared at various temperatures against $S$. aureus and $E$. coli. 


\section{MATERIALS AND METHODS}

\subsection{Preparation of AgNPs by green synthesis}

Preparation of AgNPs by green synthesis is shown in Figure $1 \mathrm{~A}$. Plant materials (Salvia officinalis) were dried at $60{ }^{\circ} \mathrm{C}$ for $48 \mathrm{~h}$ and homogenised by grinding to dust. For the preparation of the plant extract, the mixture was stirred in water $\left(20,40,60,80^{\circ} \mathrm{C}\right.$ ) for 60 minutes in a ratio of $1: 10$ followed by centrifugation ( $15 \mathrm{~min}$; $4,000 \mathrm{~g})$. The extract was mixed with $0.1 \mathrm{M} \mathrm{AgNO}_{3}(1: 1,24 \mathrm{~h})$, and the prepared particles were purified with methanol $(1: 1 ; 1 \mathrm{~h})$. After precipitation, the methanol was removed, and the AgNPs were dried at $60^{\circ} \mathrm{C}$ for 24 $\mathrm{h}$ in VWR (Radnor, Pensylvania, USA) dryer (model VDL23). The purified AgNPs were dispersed in a medium (purified water $18 \mathrm{M} \Omega$ or a mixture of water/acetone) by using ultrasound (40 minutes until a homogenous mixture was obtained) to obtain a stock solution of nanoparticles of $10 \mathrm{mg} / \mathrm{mL}$.

AgNPs were characterised by UV-VIS spectra, XRD, spectra, dynamic light (DLS) and transmission electron microscopy (Figures 1 B, C, D, E).

A
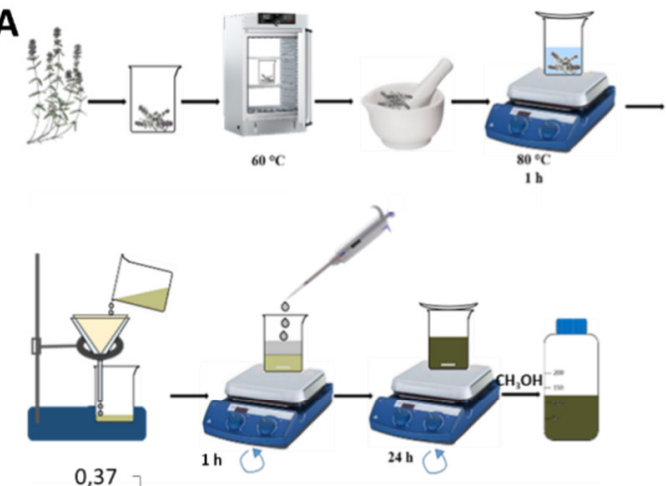

B

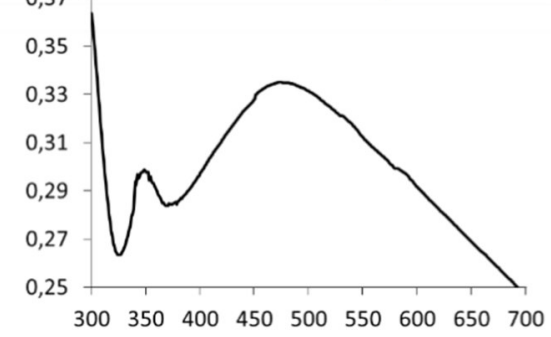

C

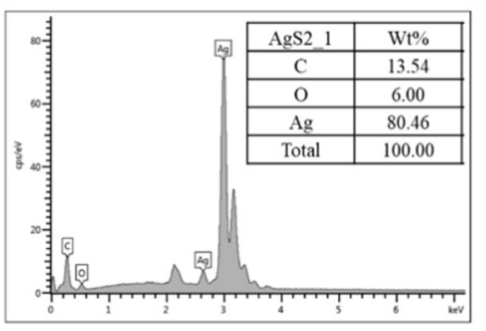

D

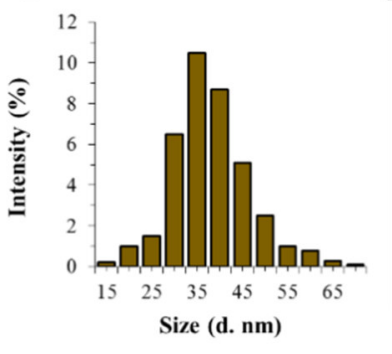

E

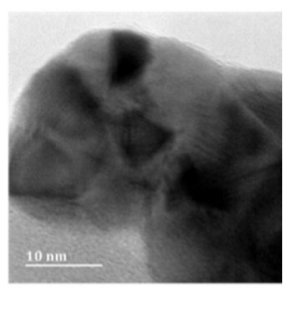

Figure 1 A) Simplified scheme of green synthesis of AgNPs. B) Typical absorbance spectrum with the maximum signal in the area of $450 \mathrm{~nm}$. C) XRD spectrum showing the presence of carbon and oxygen on the surface of AgNPs. D) The average hydrodynamic size of AgNPs measured by zeta sizer. E) TEM picture of AgNPs.

\subsection{Culture conditions and strains}

The reference strains for the first experiment (S. cerevisiae, Z. bailii, L. plantarum, L. innocua, E. coli and A. aceti) were obtained from the Colección Española de Cultivos Tipo (CECT; Valencia, Spain). The reference strains for the second experiment (E. coli and $S$. aureus) were obtained from the Czech Collection of Microorganisms (CCM, Brno, Czech Republic).

The cultures of microorganisms were stored at $4{ }^{\circ} \mathrm{C}$ in plate count agar before use. The cells from a colony of microorganisms grown on agar PCA (for $E$. coli and L. innocua) MRS (for L. plantarum and A. aceti) or YPDA (for S. cerevisiae and Z. bailii) were transferred to $10 \mathrm{~mL}$ of broth and were incubated at $30^{\circ} \mathrm{C}$ (for S. cerevisiae, Z. bailii, L. plantarum and $A$. aceti) or $37^{\circ} \mathrm{C}$ (for $E$. coli, L. innocua and S. aureus) for $24 \mathrm{~h}$ to obtain an inoculum with a density of approximately $1 \times 10^{7}$ cells $/ \mathrm{mL}$ of broth. 


\subsection{Antimicrobial susceptibility assays}

For the viable cell count method: The antimicrobial activity of the AgNPs prepared by green synthesis was determined by the microdilution method [10] with some modifications, within a range of concentration of 0 , $156.25,312.5,625,1,250$ and $2,500 \mu \mathrm{g} / \mathrm{mL}$. For this experiment, AgNPs made at $20^{\circ} \mathrm{C}$ were used in all cases. Different volumes of the stock solution $(10 \mathrm{mg} / \mathrm{mL})$ and broth media were added to 96 -well microtiter plates to obtain tested concentrations with a final volume of $200 \mu \mathrm{L}$. Then a 1-10 $\mu \mathrm{L}$ of the microbial inoculums were inoculated in microtiter plate wells to obtain a final concentration of $10^{4} \mathrm{cells} / \mathrm{mL}$. The plates were incubated at $30^{\circ} \mathrm{C}$ (for S. cerevisiae, Z. bailii, L. plantarum and A. aceti) or $37^{\circ} \mathrm{C}$ (for E. coli and L. innocua) for $24 \mathrm{~h}$. Then $100 \mu \mathrm{L}$ of samples were collected and spread on Petri dishes with PCA, MRS or YPDA. The plates were incubated for $24 \mathrm{~h}$ at $30^{\circ} \mathrm{C}$ (for S. cerevisiae, Z. bailii, L. plantarum and A. aceti) or $37^{\circ} \mathrm{C}$ (for $E$. coli and $L$. innocua) and after incubation, viable cell numbers were enumerated, and the colony-forming units per millilitre $(\mathrm{CFU} / \mathrm{mL}$ ) were determined. These values were logarithmically transformed and expressed as $\log \mathrm{CFU} / \mathrm{mL}$. The treatments were performed with at least six replicates for each condition. Positive and negative controls were included in all assays.

For the inhibition zone method [11]: Petri dishes with agar medium were covered by $50 \mu \mathrm{L}$ of bacteria suspension $\left(\mathrm{OD}_{620}=0.01\right)$. AgNPs $(c=10 \mathrm{mg} / \mathrm{mL})$ dispersion was pipetted into a Petri dish in amounts of $5,10,15$ and $20 \mu \mathrm{L}$. This resulted in variants with concentrations of 50,100,150 and nd of $200 \mu \mathrm{g} / \mathrm{mL}$. The bacteria were cultivated for $12 \mathrm{~h}$ at $37^{\circ} \mathrm{C}$. After $12 \mathrm{~h}$ of incubation, photographs were taken, and the total area of the inhibition zone in $\mathrm{cm}^{2}$ was calculated in the LIS programme (Mediapro, s.r.o., Brno, Czech Republic). When the inhibition zone began to overgrow with bacterial colonies, a constant value of $0.01 \mathrm{~cm}^{2}$ was selected.

\section{RESULTS}

\subsection{Viable cell count method results}

This method allows for identifying the number of viable cells in a given culture. Specifically, it involves counting colonies that are visible to the naked eye. Table 1 shows the microbial counts of the studied bacteria and yeast in the presence of different concentrations of the AgNPs.

Table 1 Microbial counts (log CFU/mL) of the different microorganisms after incubation with the AgNPs

\begin{tabular}{|c|c|c|c|c|c|c|}
\hline Microorganisms / Concentration & $\begin{array}{c}2,500 \\
\mu \mathrm{g} / \mathrm{ml}\end{array}$ & $\begin{array}{c}1,250 \\
\mu \mathrm{g} / \mathrm{ml}\end{array}$ & $625 \mu \mathrm{g} / \mathrm{ml}$ & $\begin{array}{c}312.5 \\
\mu \mathrm{g} / \mathrm{ml}\end{array}$ & $\begin{array}{c}156.25 \\
\mu \mathrm{g} / \mathrm{ml}\end{array}$ & $0 \mu \mathrm{g} / \mathrm{ml}$ \\
\hline E. coli & $\mathbf{0 . 8 6}$ & $\mathbf{1 . 1 8}$ & $>4$ & $>4$ & $>4$ & $>4$ \\
\hline Z. bailli & 3.30 & 3.93 & $>4$ & $>4$ & $>4$ & $>4$ \\
\hline S. cerevisiae & 3.91 & $>4$ & $>4$ & $>4$ & $>4$ & $>4$ \\
\hline L. plantarum & $>4$ & $>4$ & $>4$ & $>4$ & $>4$ & $>4$ \\
\hline L. innocua & $>4$ & $>4$ & $>4$ & $>4$ & $>4$ & $>4$ \\
\hline A. aceti & $>4$ & $>4$ & $>4$ & $>4$ & $>4$ & $>4$ \\
\hline
\end{tabular}

The results of the study show us that the silver nanoparticles have a relatively small antimicrobial effect. This occurred only in the bacterial culture of $E$. coli and yeast cultures of $Z$. bailii and $S$. cerevisiae. The effect was observed only at concentrations of 1,250 and $2,500 \mu \mathrm{g} / \mathrm{mL}$, and in $E$. coli only at concentrations of $2,500 \mu \mathrm{g} / \mathrm{mL}$.

\subsection{Zone inhibition results}

In the next part of the experimental work, the effect of the AgNPs on E. coli and S. aureus was studied using the zone inhibition method. In this method, the size of the area around each disc indicates the antimicrobial effect of the individual samples of AgNPs. For this, nanoparticles produced at $20,40,60$ and $80^{\circ} \mathrm{C}$ were used and pipetted into Petri dishes at concentrations of 50, 100, 150 and $200 \mu \mathrm{g}$ of AgNPs/mL (Figures 2A, 2B). 
A) Inhibition zones of AgNPs (S. aureus)

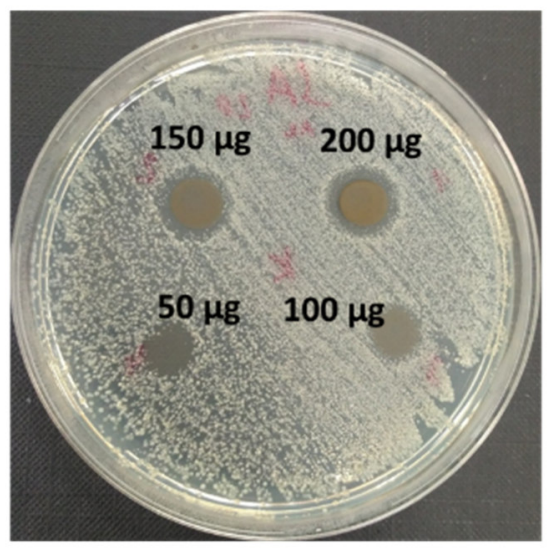

B) Inhibition zones of AgNPs (E. coli)

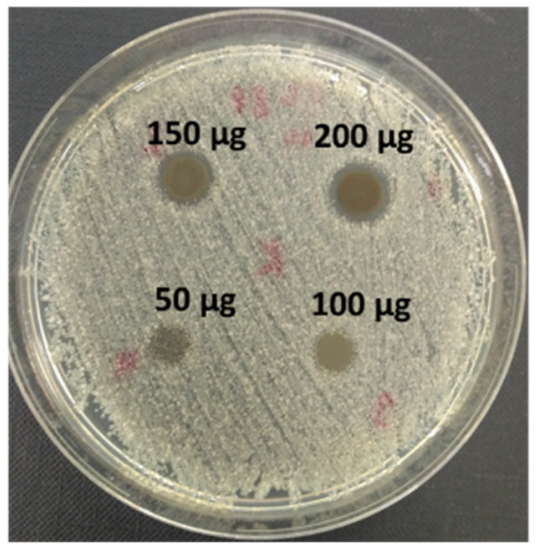

Figure 2 Typical view of inhibition zones of the agar diffusion test

Box plots showing the average value of the region of the inhibition zone were constructed from the obtained inhibition zone results (Figure 3 ).
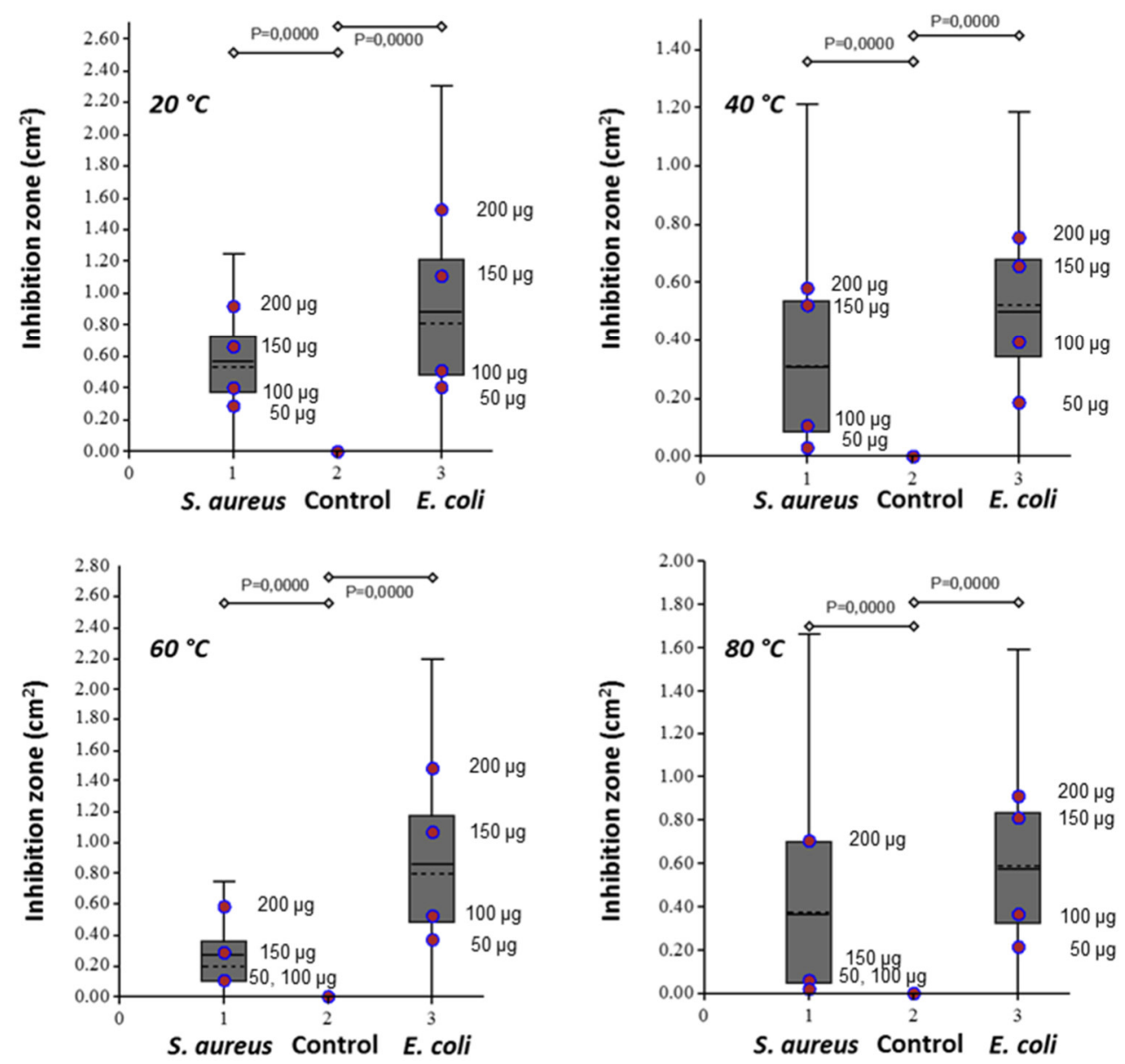

Figure 3 Box plots comparing the area of inhibition zone of AgNPs against E. coli and S. aureus. Purified sterilised water was used as a control. Four different temperatures $\left(20,40,60,80^{\circ} \mathrm{C}\right)$ were used in the process of preparing the plant extract, and four different AgNPs concentrations were tested $(50,100,150$ and $200 \mu \mathrm{g} / \mathrm{mL}$ ) 
Box plots comparing the area of the inhibition zones of AgNPs to S. aureus and E. coli. The purified water was used as a control. Inhibitor zone sizes ranged from $0.01 \mathrm{~cm}^{2}$ to $1.5 \mathrm{~cm}^{2}$. The best antibacterial effect on $S$. aureus was found with the AgNPs prepared by using the extract that was prepared at $20{ }^{\circ} \mathrm{C}$ (value $0.9 \mathrm{~cm}^{2}$ at concentration $200 \mu \mathrm{g} / \mathrm{mL}$ ). The best effect on $E$. coli also had AgNPs prepared by using the extract at $20^{\circ} \mathrm{C}$ (value $1.5 \mathrm{~cm}^{2}$ at concentration $200 \mu \mathrm{g} / \mathrm{mL}$ ). A better antibacterial effect of AgNPs was obtained against $E$. coli.

\section{CONCLUSION}

In this experimental work, silver nanoparticles were prepared using green synthesis. In the first part of the experimental work, when the $100 \mu \mathrm{L}$ nanoparticle solution was spread on Petri dishes and subsequently calculated by CFU, we were able to show a small inhibitory effect only in the bacterial culture of $E$. coli and yeast cultures of $Z$. bailii and $S$. cerevisiae.

In the second part of the experiment, four different amounts (50,100, 150 and $200 \mu \mathrm{g}$ of $\mathrm{AgNPs} / \mathrm{mL})$ produced at four different temperatures $\left(20,40,60\right.$ and $\left.80^{\circ} \mathrm{C}\right)$ were pipetted onto the Petri dishes. The detection of differences in the size of the inhibition zones in the preparation at different temperatures was critical. The best antibacterial effect to $E$. coli and also $S$. aureus was found with the AgNPs prepared by using the extract that was prepared at $20^{\circ} \mathrm{C}$. In the future we anticipate the study of antimicrobial activity using different extraction times of the biological matrix and other solvents.

\section{ACKNOWLEDGEMENTS}

The work was carried out with the support of the H2020 CA COST Action CA15114, INTER-COST LTC18002.

\section{REFERENCES}

[1] KAMRAN, U., BHATTI, H. N., IQBAL, M., NAZIR, A. Green Synthesis of Metal Nanoparticles and their Applications in Different Fields: A Review. Zeitschrift Fur Physikalische Chemie-International Journal of Research in Physical Chemistry \& Chemical Physics, 2019, vol. 233, no. 9, pp. 1325-1349.

[2] AHMAD, S., MUNIR, S., ZEB, N., ULLAH, A., KHAN, B., ALI, J., BILAL, M., OMER, M., ALAMZEB, M., SALMAN, S. M., ALI, S. Green nanotechnology: a review on green synthesis of silver nanoparticles - an ecofriendly approach. International Journal of Nanomedicine, 2019, vol. 14, no. pp. 5087-5107.

[3] AHMED, M. J., MURTAZA, G., MEHMOOD, A., BHATTI, T. M. Silver nanoparticles, green synthesis: characterization, in vitro antioxidant and antimicrobial study. Inorganic and Nano-Metal Chemistry, vol., no. pp. 9.

[4] SHARMA, V. K., YNGARD, R. A., LIN, Y. Silver nanoparticles: Green synthesis and their antimicrobial activities. Advances in Colloid and Interface Science, 2009, vol. 145, no. 1-2, pp. 83-96.

[5] ROSE, G. K., SONI, R., RISHI, P., SONI, S. K. Optimization of the biological synthesis of silver nanoparticles using Penicillium oxalicum GRS-1 and their antimicrobial effects against common food-borne pathogens. Green Processing and Synthesis, 2019, vol. 8, no. 1, pp. 144-156.

[6] CORCIOVA, A., IVANESCU, B., TUCHILUS, C., FIFERE, A., DOROFTEI, F., LUNGOCI, A. L., MARANGOCI, N., MIRCEA, C. BIOSYNTHESIS OF SILVER NANOPARTICLES (AgNPS) USING Tilia cordata FLOWERS EXTRACTS AND EVALUATION OF SOME BIOLOGICAL ACTIVITIES. Environmental Engineering and Management Journal, 2018, vol. 17, no. 12, pp. 2957-2968.

[7] JASICKA-MISIAK, I., POLIWODA, A., PETECKA, M., BUSLOVYCH, O., SHLYAPNIKOV, V. A., WIECZOREK, P. P. ANTIOXIDANT PHENOLIC COMPOUNDS IN Salvia officinalis L. AND Salvia sclarea L. Ecological Chemistry and Engineering S-Chemia I Inzynieria Ekologiczna S, 2018, vol. 25, no. 1, pp. 133-142. 
[8] FOTOVVAT, M., RADJABIAN, T., SABOORA, A. HPLC Fingerprint of Important Phenolic Compounds in Some Salvia L. Species from Iran. Records of Natural Products, 2019, vol. 13, no. 1, pp. 37-49.

[9] EL EUCH, S. K., HASSINE, D. B., CAZAUX, S., BOUZOUITA, N., BOUAJILA, J. Salvia officinalis essential oil: Chemical analysis and evaluation of anti-enzymatic and antioxidant bioactivities. South African Journal of Botany, 2019, vol. 120, no. pp. 253-260.

[10] CLSI, Reference method for broth dilution antifungal susceptibility testing of yeasts: approved standard - Third edition, CLSI document M27-A3, 950 West Valley Road, Suite 2500, Wayne, Pennsylvania 19087, USA, 2008.

[11] CLSI, Performance Standards for Antimicrobial Disk Susceptibility Tests, Approved Standard, 7th ed., CLSI document M02-A11. Clinical and Laboratory Standards Institute, 950 West Valley Road, Suite 2500, Wayne, Pennsylvania 19087, USA, 2012. 